\title{
Quality Evaluation of Theses in Teaching Science and Mathematics Program
}

\author{
Prasart Nuangchalerm \\ Faculty of Education, Mahasarakham University, Thailand \\ E-mail: prasart.n@msu.ac.th \\ Veena Prachagool (Corresponding author) \\ Faculty of Education, Mahasarakham University, Thailand \\ E-mail: veena.p@msu.ac.th
}

Received: November 2, $2021 \quad$ Accepted: December 1, 2021

Published: December 13, 2021

doi:10.5296/jei.v7i2.19140ＵRL: https://doi.org/10.5296/jei.v7i2.19140

\begin{abstract}
This study aimed to study quality of theses of master education program in teaching science and mathematics, Mahasarakham University, Thailand which conducted and published during 2016-2019. A 37 theses were studied through systematic approach. Data were collected by 24 questionnaires of theses analysis anecdotal. Mean, standard deviation, and percentage were employed. Results showed that most of thesis focus on action research due to the school contexts. Teaching strategies or innovation which employed are problem-based learning, inquiry-based learning, STEM education and other trending approaches. All of informants or samples are studying in high school level. Overall of quality of thesis can be considered in at good level. The finding is useful for program development and shaping research area for graduate students in the future.
\end{abstract}

Keywords: Evaluation, Graduate studies, Research, Thesis

\section{Introduction}

Research is a search for truth through reliable methods and credible cognitive review process. The research is varied and the way of its knowledge is studied depends on the purpose of the research. It can be defined as the heart knowledge construction, the development of knowledge, and natural phenomena explanation, and exploration between scientific and societal implications (Fowler \& Cherrstrom, 2017; Liljedahl, 2018). Specific knowledge 
needs more power of knowledge construction by specialist, different methods for describing how it works and effects to social growth. The process in knowledge development employed reliable methods and acceptable process to professions. Research not only process, but also ethics and moral are important to researchers. It enables to develop knowledge and grow their academic scholars (Feldman et al., 2013). As a result, society has high expectations that when graduates of this level have knowledge, they will be able to learn more. Research ability, morality, ethics, and academic ethics, and create academic circles to be socially reliant which is an important mission and will be neglected (O'Clair, 2013).

Graduate students have to do a research based on regulation and program standards. They how to enrolled coursework and thesis, research can be done through conducting and self-study via thesis. With the completely programmed in the purpose to them, thesis allow think and do by employing scientific method and suitable, reliable, and credible methods. Thesis is one of the most thing that important practical work in graduate studies (Bui, 2013). It focuses on creative ideas for exploring new knowledge or knowledge applications in different field. Some thesis may be argued into a broader model or approaches. That is, it's not only ideas or knowledge construction by self, but it useful for public understanding of what have learned and represent to society (Badenhorst et al., 2015).

Thesis have two basic concepts in what ideas are about and what ideas are. Thesis is also reported of what researcher(s) think and do with reliable process and the report significant results. It will be written by academic writing and proving of what researcher(s) learned from critical study with advisor or expert in their field (Kayode \& Ngozi, 2014; Kuehne et al., 2014). It showed an important exploration that can be written into scientific writing and can be provable by others. Thesis should not be too broad, but narrow required,

Master of Education Program in Teaching Science and Mathematics, Mahasarakham University, Thailand has been launched since 2014. The program aims to produce master's degrees of academic excellence and expertise in teaching science and mathematics. Students must enroll in basic and specialized subjects and thesis subjects which must be supervised and consulted by the thesis advisor in order to create knowledge, teaching that can be applied to the benefits of education. Graduate teaching aims to enhance knowledge and enhance the skills of researchers and specialize in the field of science.

Therefore, the teaching aims to cultivate academic attributes by studying various subjects and conducting research to complete the study. This study tries to explore trends of thesis in this field and investigate the critical findings in specific reports. Due to this program promote students in both coursework and research conducting, but it may be varied by nature of study, thesis regulation and its process, limitation by unpredictable, and role of advisor. However, the study employ thesis which published in library and online access for analyzing and evaluating quality based on thesis output and the refer to process by scientific explanation.

Thesis is an output of mostly knowledge that graduate students pay their attention to work and report of what they have learned with advisors (Erichsen et al., 2014; Beres \& Dixon, 2016). Students at this level must develop themselves with both intensive academic knowledge, research skills and research experience to create new knowledge. Throughout the 
process of conducting thesis in the form of exams and presenting them in a complete form and/or publishing the results of their studies in academic journals. Thesis is part of a course that reflects academic elegance which requires knowledge. The commitment to overcome obstacles and the need to write a complete thesis report is made public. Thesis is an academic evidence that demonstrates the academic potential and incubation process of the disciplines to be strong and distinctive of the students.

Therefore, the thesis is a trace of the work and learn through academic track. This research aims to evaluate the quality of thesis in master of education program, especially science and mathematics teaching. The information obtained will be the information and thesis development guidelines of this field to be more quality.

\section{Materials and Methods}

The study is an exploratory research aimed at assessing the quality of the master's thesis. These theses were published between 2016 and 2019. Scope of research can be described in the following.

(1) The samples are thesis, master of education in science and mathematics teaching. Mahasarakham University, published between 2016 and 2019 from 37 volumes (based on the thesis database of thesis of Mahasarakham University, Thailand (http://www.library.msu. ac.th).

(2) Methods of thesis conduction were studied.

The study features include: Information related to researchers and researchers which consisted of year of printing and major of study, Information about design and research methods which consisted of population or samples; population sampling method; variables; research tools; data collection; data analysis; and statistics used. Thesis quality assessment by the thesis quality assessment based on the actual condition, which has a total of 24 items.

\subsection{Samples}

Samples include theses of master's degree in teaching science and mathematics program, Mahasarakham University, Thailand which published during 2016-2019. A 37 volumes are found and selection for analyzing and evaluating as well.

\subsection{Research Tools}

Thesis feature record: researcher studied and reviewed the literature related to the thesis. Then it was created a pattern to record the features, synthesize the data to check the accuracy and appropriateness of the data recording. Data were collected by critical reading each thesis and recording the reporting information on each issue considered in a synthetic form. Verifying the accuracy of the data collection in order to provide clarity on the recording. Also, thesis quality assessment was employed: study and review the literature related to thesis quality assessment. The thesis quality recording was created, it is established for qualified quality inspectors based on accuracy and clarity. It was to check the accuracy by 5-rating score by very good, good, moderate, not good, and not very good. 


\subsection{Data Collection}

Researcher surveyed thesis in the field of teaching science and mathematics, searched and compiled the thesis from thesis database of MSU Library, Mahasarakham University (http://www.library.msu.ac.th) to assess the quality of the thesis graduated during 2016-2019. A 37 volumes were recorded, then check the integrity of its details to references. Researchers studied the integrity of the thesis and its composition, the general information of the thesis was classified and analyzed. The process of thesis evaluation was conducted by adapted from Buasonse et al. (2014), Piyanuwat (2016), which was a 5-level scale assessment consisting of very good, good, moderate, not good, and not very good. The number of 24 items were employed for data collection. Data were recorded and evaluated the quality of the thesis according to the issues set out in the actual assessment.

\subsection{Data Analysis}

Evaluate the thesis quality by analyzing in each issue, consideration and evaluation were descriptive statistics including frequency, percentage, mean, and standard deviation. Data were analyzed by percentages, mean, and standard deviation. The results of each items can be assessed and reported by using the interpretation criteria as follows (Table 1).

Table 1. Interpretation criteria

\begin{tabular}{|l|l|}
\hline Average & Quality Level \\
\hline $4.51-5.00$ & Very good \\
\hline $3.51-4.50$ & Good \\
\hline $2.51-3.50$ & Moderate \\
\hline $1.51-2.50$ & Not good \\
\hline $1.00-1.50$ & Not Very good \\
\hline
\end{tabular}

Additional findings or observations of each book will be recorded and categorized to be presented with analytical analysis.

\section{Result}

The study revealed that 37 theses provide a significant information to field of teaching science and mathematics. The general information showed that mostly theses concern constructivism, practical work, problem-based learning, inquiry-based learning, and other instructional strategies. When sorting in descending order it was found that in 2017 (14 volumes), 2019 (13 volumes), 2016 (9 volumes), and 2018 (1 volume). The most popular research methodology used in the thesis consists of action research (22 volumes). All thesis collected data from high school students in various major of teaching, 26 volumes were science and 11 were mathematics. More details as shown in Table 2. 
Table 2. General information of theses used to evaluate quality

\begin{tabular}{|c|c|c|c|c|c|}
\hline Year & Volume & Research Methodology & Major & Informant & Innovation \\
\hline 2016 & 9 & Research \& Development (9) & $\begin{array}{l}\text { Science (8) } \\
\text { Mathematics (1) }\end{array}$ & $\begin{array}{l}\text { Grade } 10(8) \\
\text { Grade } 11(1)\end{array}$ & $\begin{array}{l}\text { Problem-based learning (3) } \\
\text { Flipped classroom (1) } \\
\text { STEM education (1) } \\
\text { Content-oriented integration (1) } \\
\text { Experiential learning (1) } \\
\text { Socio-scientific issues (1) } \\
\text { Constructivism (1) }\end{array}$ \\
\hline 2017 & 14 & $\begin{array}{l}\text { Research \& Development (4) } \\
\text { Operational Research (4) }\end{array}$ & $\begin{array}{l}\text { Science (10) } \\
\text { Mathematics (4) }\end{array}$ & $\begin{array}{l}\text { Grade } 10(7) \\
\text { Grade } 11(6) \\
\text { Grade } 12(1)\end{array}$ & $\begin{array}{l}\text { Problem-based learning (5) } \\
\text { Problem-based and } \\
\text { Project-based learning (1) } \\
\text { Inquiry-based STEM education (1) } \\
\text { Experiential learning (1) } \\
\text { Socio-scientific issues (1) } \\
\text { Simulation (1) } \\
\text { PDEODE (1) } \\
\text { Polya + KWDL + } \\
\text { Cognitive process (1) } \\
\text { Evidence-based learning (1) }\end{array}$ \\
\hline 2018 & 1 & Operational Research (1) & Science (1) & Grade 11 (1) & Inquiry-based learning (1) \\
\hline 2019 & 13 & $\begin{array}{l}\text { Research \& Development (1) } \\
\text { Operational Research (11) } \\
\text { Experimental Research (1) }\end{array}$ & $\begin{array}{l}\text { Science (7) } \\
\text { Mathematics (10) }\end{array}$ & $\begin{array}{l}\text { Grade } 10(6) \\
\text { Grade } 11(7)\end{array}$ & $\begin{array}{l}\text { Problem-based learning (3) } \\
\text { Problem-based and Project-based learning (1) } \\
\text { Inquiry-based learning (1) } \\
\text { Inquiry-based STEM education (2) } \\
\text { Cooperative learning (1) } \\
\text { SSCS (1) } \\
\text { PODE (1) } \\
\text { Polya (3) }\end{array}$ \\
\hline
\end{tabular}

Theses quality in overall is at good $(\bar{X}=3.89, \mathrm{SD}=0.37)$, quality can be ranked from the most consistent with research issues $(\mathrm{X}=3.95, \mathrm{SD}=0.42)$, clear problem proposal $(\mathrm{X}=$ $3.92, \mathrm{SD}=0.37)$, data collection corresponds to the tool $(\mathrm{X}=3.92 \mathrm{SD}=0.28)$, statistics used to analyze the data are consistent with the research objectives $(X=3.92 \mathrm{SD}=0.37)$, the recommendations are consistent with the findings $(\mathrm{X}=3.92, \mathrm{SD}=0.32)$, and suggestions can be implemented $(\mathrm{X}=3.92 \mathrm{SD}=0.28)$ in the following (Table 3). 
Table 3. Quality of thesis in each item

\begin{tabular}{|c|c|c|c|c|}
\hline No. & Item & $\bar{X}$ & SD & Quality level \\
\hline 1 & The proposal of the problem is clear & 3.92 & 0.37 & Good \\
\hline 2 & The research problem is important & 3.85 & 0.36 & Good \\
\hline 3 & The problem is reasonably credible & 3.90 & 0.32 & Good \\
\hline 4 & The research objectives align the problem & 3.82 & 0.38 & Good \\
\hline 5 & The research hypothesis is consistent with the research objectives & 3.90 & 0.40 & Good \\
\hline 6 & The scope of the research is consistent with the research issues & 3.95 & 0.42 & Good \\
\hline 7 & Variable definitions or term definitions are clear & 3.85 & 0.45 & Good \\
\hline 8 & Related documents and research cover variables & 3.85 & 0.45 & Good \\
\hline 9 & Ability to synthesize documents or research & 3.85 & 0.38 & Good \\
\hline 10 & Population determination is consistent with research issues & 3.90 & 0.32 & Good \\
\hline 11 & Clear population determination & 3.90 & 0.32 & Good \\
\hline 12 & The sampling method is appropriate for the characteristics of the population & 3.90 & 0.32 & Good \\
\hline 13 & A sample that can represent the population & 3.92 & 0.28 & Good \\
\hline 14 & Variable fit to research tools & 3.90 & 0.32 & Good \\
\hline 15 & The development of research tools is appropriate & 3.90 & 0.32 & Good \\
\hline 16 & Research tools are reliable & 3.90 & 0.32 & Good \\
\hline 17 & Data collection is consistent with the research tools & 3.92 & 0.28 & Good \\
\hline 18 & The statistics used to analyze the data are consistent with the research objectives & 3.92 & 0.37 & Good \\
\hline 19 & The results of the analysis are consistent with the research objectives & 3.82 & 0.49 & Good \\
\hline 20 & Results are clearly analyzed & 3.85 & 0.47 & Good \\
\hline 21 & The conclusion of the findings is consistent with the research objectives & 3.90 & 0.49 & Good \\
\hline 22 & The discussion is reasonably fruitful & 3.85 & 0.53 & Good \\
\hline 23 & The recommendations are consistent with the findings & 3.92 & 0.32 & Good \\
\hline 24 & Suggestions can be implemented & 3.92 & 0.28 & Good \\
\hline \multicolumn{2}{|c|}{ Average } & 3.89 & 0.37 & Good \\
\hline
\end{tabular}

However, some findings from the thesis evaluation also showed that some thesis titles were incomplete, titles missed informants or taught topics, literature reviews are not cover innovation and variables. Research problem not makes its correlation with innovation, lack of 
alignment between problems and innovations. The terminology definition includes a non-comprehensive term definition and incomplete definition. The objectives lack clarity, documentation and related research, namely the review is not yet concise. Document and significant references are rarely complete, and references are quite obsolete. The acquisition of samples or informants is lack in details. The presentation of the finding the quality is not exhaustive and lacks detail. The research also has a discrepancy in how research is conducted, and the presentation of the findings is not related to the objectives. The discussion also lacks coherence and lacks support theory.

\section{Discussion}

The study found that all of thesis items are at good level, that is, thesis process pay attention to think what ideas are. Graduate students work with advisor in different working styles, but quality or academic standard is aware to all students. By the nature of science and mathematics, system thinking is critical point help students learn in both science and social science by skeptical ways. They attend coursework for making general concept about education, but they can fulfill science or mathematics as well as they want to classroom (Serbes \& Albay, 2017). Then, thesis is invited, but it is not only subject in the program of study that is process to engage research characteristics in the suitable time. They have to study previous research reports and make alignment research topics based on classroom contexts.

The study showed what instructional practices that they employed into thesis. It is trending innovation for several science and mathematics classroom (O'Toole et al., 2018; Skamp, 2020). They employed problem-based learning as key innovation for conducting research and improving students in various kinds of objectives. Not only problem-based learning is reported, but also inquiry-based learning and other practical works, i.e., project-based learning, cooperative learning, STEM education and so on are implemented to solve their classroom problem. Due to the literature reviews or making alignment between research problem and instructional practices make its correlate (Tsai \& Lydia Wen, 2005). However, the different educational contexts may be resulted in different answers, but not quite different as it be. The research design based on schooling showed a highlight of research experiences such as action research, experimental research, research and development are broader model for thesis conduction.

The instructional practices that they implemented are distinctive theory in field of science and mathematics education. Constructivism is a root of theoretical support in field of science and mathematics, it is a basis philosophy of practical works such as inquiry-based learning, problem-based learning, project-based learning and others. The findings regarding to the contribution of research interest by different literature reviews and school contexts which according to nature of topics in teaching and level of students (Panasan \& Nuangchalerm, 2010; Nuangchalerm et al., 2020; Tuğrul Mart, 2020). Thesis mostly employed action research and research \& development due to the program of study allow graduate students in 2 -year study in both coursework and research conduction. Graduate students in this program have to complete their thesis in the duration as program designed. Then, research design must 
be suitable and enable them to learn in a limiting time and anxiety about their thesis conduction (Prachagool et al., 2021). However, this research just describes what explore in the theses report, it also is an indicator of a need for more complicated research designs. It can inform reader to understand in the possibility to understand how graduate students from the program of study.

Thesis is an output to show how graduate students think, do, and learn throughout possible and reliable process. Quality of each thesis may be varied by academic standards, students learn though peer instruction or advisor as mentor (Holley \& Caldwell, 2012; Bagaka's et al., 2015; Feldon et al., 2015; DuVivier \& Patitu, 2017). So, it is very difficult to consider that how thesis make its value into education or social impacts. The research methods and findings should be made it public use or accept by scholars in specific field of education. That is, each thesis should be summarized and generalized to academic journal or participating conference. Graduate students will learn more how to be good researchers, way of professional educational researcher, self-reform in what universal scholars think and do, and ethics/responsibilities which researchers should have (Hastings et al., 2017; Prachagool \& Nuangchalerm, 2021).

\section{Conclusion}

Results showed that most of thesis focus on action research due to the school contexts. Teaching strategies or innovation which employed are problem-based learning, inquiry-based learning, STEM education and other trending approaches. All of informants or samples are studying in high school level. Overall of quality of thesis can be considered in at good level.

\section{Acknowledgements}

This research project is financially supported by Mahasarakham University, Thailand.

\section{References}

Badenhorst, C., Moloney, C., Rosales, J., Dyer, J., \& Ru, L. (2015). Beyond deficit: Graduate student research-writing pedagogies. Teaching in Higher Education, 20(1), 1-11. https://doi.org/10.1080/13562517.2014.945160

Bagaka's, J. G., Badillo, N., Bransteter, I., \& Rispinto, S. (2015). Exploring student success in a doctoral program: The power of mentorship and research engagement. International Journal of Doctoral Studies, 10(1), 323-342. https://doi.org/10.28945/2291

Beres, J. L., \& Dixon, J. C. (2016). Examining the role of friendship in mentoring relationships between graduate students and faculty advisors. Collected Essays on Learning and Teaching, 9, 111-124. https://doi.org/10.22329/celt.v9i0.4440

Bui, Y. N. (2013). How to write a master's thesis. Sage Publications.

DuVivier, R., \& Patitu, C. (2017). Effects of study abroad on graduate student dispositions, knowledge and skills. College Student Affairs Journal, 35(2), 15-28. https://doi.org/10.1353/ csj.2017.0010 
Eğmir, E., Erdem, C., \& Koçyiğit, M. (2017). Trends in educational research: A content analysis of the studies published in International Journal of Instruction. International Journal of Instruction, 10(3), 277-294. https://doi.org/10.12973/iji.2017.10318a

Erichsen, E. A., Bolliger, D. U., \& Halupa, C. (2014). Student satisfaction with graduate supervision in doctoral programs primarily delivered in distance education settings. Studies in Higher Education, 39(2), 321-338. https://doi.org/10.1080/ 03075079.2012.709496

Feldman, A., Divoll, K. A., \& Rogan-Klyve, A. (2013). Becoming researchers: The participation of undergraduate and graduate students in scientific research groups. Science Education, 97(2), 218-243. https://doi.org/10.1002/sce.21051

Feldon, D. F., Maher, M. A., Hurst, M., \& Timmerman, B. (2015). Faculty mentors', graduate students', and performance-based assessments of students' research skill development. American Educational Research Journal, 52(2), 334-370. https://doi.org/10.3102/000283 1214549449

Fowler, D., \& Cherrstrom, C. A. (2017). Graduate student perception of teaching development in a college teaching course. NACTA Journal, 61(2), 150-156.

Hastings, A., Stockley, D., Kinderman, L., \& Egan, R. (2017). Graduate student research in the classroom-Understanding the role of research ethics. College Student Journal, 50(3), 361-368.

Holley, K. A., \& Caldwell, M. L. (2012). The challenges of designing and implementing a doctoral student mentoring program. Innovative Higher Education, 37(3), 243-253. https://doi.org/10.1007/s10755-011-9203-y

Kayode, O. G., \& Ngozi, A. (2014). Variables attributed to delay in thesis completion by postgraduate students. Journal of Emerging Trends in Educational Research and Policy Studies, 5(1), 6-13.

Kuehne, L. M., Twardochleb, L. A., Fritschie, K. J., Mims, M. C., Lawrence, D. J., Gibson, P. P., ... Olden, J. D. (2014). Practical science communication strategies for graduate students. Conservation Biology, 28(5), 1225-1235. https://doi.org/10.1111/cobi.12305

Liljedahl, P. (2018). Mathematics education graduate students' thoughts about becoming researchers. Canadian Journal of Science, Mathematics and Technology Education, 18(1), 42-57. https://doi.org/10.1007/s42330-018-0007-2

Nuangchalerm, P., Prachagool, V., Prommaboon, T., Juhji, J., Imroatun, I., \& Khaeroni, K. (2020). Views of primary Thai teachers toward STREAM education. International Journal of Evaluation and Research in Education, 9(4), 987-992. https://doi.org/10.11591/ijere.v9i4. 20595

O’Toole, J. M., Freestone, M., McKoy, K. S., \& Duckworth, B. (2018). Types, topics and trends: A ten-year review of research journals in science education. Education Sciences, 8(2), 73. https://doi.org/10.3390/educsci8020073 
O'Clair, K. (2013). Preparing graduate students for graduate-level study and research. Reference Services Review, 41(2), 336-350. https://doi.org/10.1108/00907321311326255

Panasan, M., \& Nuangchalerm, P. (2010). Learning outcomes of project-based and inquiry-based learning activities. Journal of Social Sciences, 6(2), 252-255.

Prachagool, V., \& Nuangchalerm, P. (2021). Perspectives of Thai educators toward 21st century instruction. Journal of Education and Learning (EduLearn), 15(3), 432-437. https://doi.org/10.11591/edulearn.v15i3.20281

Prachagool, V., Nuangchalerm, P., Juhiji, J., \& Thavornsil, T. (2021). Researching anxiety of pre-service teachers in teaching science and mathematics program. Journal of Education and Learning (EduLearn), 15(3), 438-442. https://doi.org/10.11591/ edulearn.v15i3.20282

Serbes, M., \& Albay, M. (2017). Importance of career planning and development in education. International Journal of Social Sciences \& Educational Studies, 4(2), 149-154. https://doi.org/10.23918/ijsses.v4i2sip149

Skamp, K. (2020). Research in Science Education (RISE): A review (and story) of research in RISE articles (1994-2018). Research in Science Education, 1-33. https://doi.org/10.1007/ s11165-020-09934-w

Tsai, C. C., \& Lydia Wen, M. (2005). Research and trends in science education from 1998 to 2002: A content analysis of publication in selected journals. International Journal of Science Education, 27(1), 3-14. https://doi.org/10.1080/0950069042000243727

Tuğrul Mart, Ç. (2020). Integrating listening and speaking skills to promote speech production and language development. MEXTESOL Journal, 44(2), 1-7.

\section{Copyright Disclaimer}

Copyright for this article is retained by the author(s), with first publication rights granted to the journal.

This is an open-access article distributed under the terms and conditions of the Creative Commons Attribution license (http://creativecommons.org/licenses/by/3.0/). 